\title{
Ekstraksi kolagen dari kulit kerbau menggunakan asam asetat
}

\section{Extraction of collagen from buffalo hide by acetic acid}

\author{
Sri Mulyani ${ }^{1 *}$, Antonius Hintono ${ }^{1}$, Neisya Nurizqi Adefatma ${ }^{1}$, Iwan Fajar Pahlawan ${ }^{2}$ \\ ${ }^{1}$ Program Studi Teknologi Pangan, Departemen Pertanian, Fakultas Peternakan dan Pertanian, Universitas Diponegoro, Jl. \\ Prof. H. Sudarto, SH, Semarang 50275, Indonesia \\ ${ }^{2}$ Balai Besar Kulit, Karet dan Plastik, Kementerian Perindustrian, Jl. Sokonandi No. 9, Yogyakarta 55166, Indonesia \\ *Penulis korespondensi. Telp. 08155112481 \\ e-mail: srimulyani@lecturer.undip.ac.id
}

Diterima: 25 Mei 2021

Direvisi: 31 Agustus 2021

Disetujui: 2 September 2021

\begin{abstract}
Buffalo hide is potential as an alternative raw material for making halal collagen to substitute those made from cow and porcine. However, the complexity of buffalo hide is higher than cattle hide and pigskin. Acetic acid is a weak acid that is able to extract collagen properly. The study aimed to determine the effect and the interaction of various concentrations of acetic acid and extraction time on collagen quality, including yield, water content, and collagen's characteristics based on molecular weight and functional groups. The main research material was 3 (three) sides of male buffalo (swamp buffalo) skin aged 3-4 years. This study was an experimental research with factorial completely randomized design, which consisted of the factor of acetic acid concentrations (3\%, 5\%, 7\%) and the factor of extraction times (48 hours and 72 hours). All treatments were replicated four times. The optimum result of buffalo hide collagen extraction was using a concentration of $1 M$ acetic acid with 72 hours extraction time that produced collagen with the yield of $1.42 \pm 0.27 \%$, based on the concentration factor, and the yield of 1.70 $\pm 0.35 \%$, based on the extraction time factor, $4.19 \pm 0.14 \%$ water content, and it was identified that collagen has not yet been degraded into gelatin based on molecular weight and functional groups.
\end{abstract}

Keywords: acetic acid, buffalo hide, collagen.

\begin{abstract}
ABSTRAK
Kulit kerbau berpotensi sebagai bahan baku alternatif pembuatan kolagen halal, pengganti sapi dan babi. Namun, kompleksitas kulit kerbau diduga lebih tinggi dibandingkan kulit sapi maupun kulit babi. Asam asetat merupakan asam lemah yang mampu mengekstraksi kolagen dengan baik. Penelitian ini bertujuan untuk mengetahui pengaruh dan interaksi berbagai konsentrasi asam asetat dan waktu ekstraksi terhadap kualitas kolagen, diantaranya rendemen, kadar air, serta karakteristik kolagen, berdasarkan berat molekul dan gugus fungsi. Materi utama penelitian ini berupa 3 lembar kulit kerbau rawa jantan berumur 3-4 tahun. Studi ini merupakan penelitian eksperimen dengan rancangan acak lengkap pola faktorial, yang terdiri dari faktor konsentrasi asam asetat $(0,5$ M, 1 M, 1,5 M) dan waktu ekstraksi (48 jam dan 72 jam). Seluruh perlakuan direplikasi sebanyak empat kali. Hasil optimum ekstraksi kolagen dari kulit kerbau adalah menggunakan asam asetat dengan konsentrasi $1 \mathrm{M}$ dengan ekstraksi selama 72 jam, dimana menghasilkan kolagen dengan rendemen 1,42 $\pm 0,27 \%$, berdasarkan faktor konsentrasi, dan $1,70 \pm 0,35 \%$, berdasarkan faktor lama ekstraksi, kadar air 4,19 $\pm 0,14 \%$, serta teridentifikasi bahwa kolagen belum mengalami degradasi menjadi gelatin berdasarkan berat molekul dan gugus fungsi.
\end{abstract}

Kata kunci: asam asetat, kolagen, kulit kerbau.

\section{PENDAHULUAN}

Kolagen merupakan jenis protein yang dominan terhadap total protein tubuh makhluk hidup secara keseluruhan, yakni mencapai $30 \%$. 
Kolagen merupakan penyusun jaringan pengikat yang salah satunya dapat ditemukan di bagian kulit (Darmanto et al., 2012). Kulit, sebagai salah satu hasil samping dari pemotongan hewan ternak, seperti kerbau, keberadaannya cukup melimpah di Indonesia serta memiliki potensi ekonomi namun belum dimanfaatkan secara maksimal. Kulit kerbau mengandung protein kolagen yang dapat dimanfaatkan dalam industri pengolahan, baik pangan maupun non pangan, seperti industri makanan, industri kosmetik, dan industri farmasi (Kolanus et al., 2019). Secara umum, kolagen komersial berasal dari hewan sapi maupun babi. Hal tersebut menjadi suatu permasalahan di Indonesia karena babi merupakan hewan yang diharamkan bagi umat muslim dan dikhawatirkan mengandung penyakit flu babi, sedangkan sapi dilarang bagi pemeluk agama Hindu dan dikhawatirkan terjangkit penyakit sapi gila (Ata et al., 2016). Pemenuhan kebutuhan kolagen di Indonesia juga masih berasal dari negara lain, maka perlu adanya alternatif lain sebagai sumber kolagen dengan memanfaatkan kulit kerbau serta usaha untuk dapat memproduksi kolagen sendiri. Kolagen dapat diperoleh dengan cara ekstraksi secara enzimatis maupun kimiawi. Ekstraksi kimiawi salah satunya menggunakan asam.

Asam asetat merupakan asam organik yang memiliki kemampuan mengekstrak kolagen lebih baik dibandingkan pelarut lain seperti asam sitrat maupun asam klorida (Ariyanti et al., 2018). Penelitian ekstraksi kolagen dengan asam asetat telah dilakukan oleh Rizk dan Mostafa (2016) dan menghasilkan rendemen yang rendah pada konsentrasi asam asetat $0,5 \mathrm{M}$ dan lama ekstraksi 24 jam. Pada penelitian tersebut belum dilakukan optimasi konsentrasi dan lama ekstraksi serta pengaruhnya terhadap karakteristik kolagen yang dihasilkan. Konsentrasi asam yang terlalu tinggi dapat menyebabkan terjadinya hidrolisis lanjut sehingga rantai kolagen berubah menjadi gelatin. Selain itu, lama ekstraksi dengan perendaman dalam asam harus dilakukan dengan tepat. Semakin lama ekstraksi maka semakin besar penyerapan air oleh kulit dimana serat kolagen menjadi semakin mudah terpisah dari kulit dan mempermudah proses ekstraksi (Astiana et al., 2016). Perendaman yang dilakukan terlalu lama akan mempengaruhi kelarutan kolagen sehingga dapat menyebabkan terjadinya kehilangan kolagen. Penggunaan metode acid solubilition dalam proses ekstraksi kolagen dari kulit sapi, dengan menggunakan asam asetat pada konsentrasi 0,5 M selama 24 jam, menghasilkan rendemen 3,8\% (Noorzai et al., 2020). Oleh karena itu, penelitian tentang ekstraksi kolagen perlu dilakukan dengan menggunakan asam asetat pada konsentrasi dan waktu ekstraksi yang beragam untuk menentukan perlakuan yang terbaik sehingga dapat menghasilkan yield kolagen dari kulit kerbau dan karakteristik tetap sesuai standar. Penelitian ini bertujuan untuk mengetahui pengaruh dan interaksi atas penggunaan konsentrasi asam asetat dan lama ekstraksi yang berbeda, terhadap rendemen, kadar air, serta karakteristik kolagen berdasarkan berat molekul dan gugus fungsional.

\section{BAHAN DAN METODE \\ Bahan Penelitian}

Bahan utama yang digunakan adalah kulit kerbau jantan dengan usia sekitar 3-4 tahun, yang diperoleh dari CV. Panji Jaya, Pleret, Bantul, Daerah Istimewa Yogyakarta. Sedangkan bahan pembantu yang digunakan meliputi silica gel, asam asetat, $\mathrm{NaOH}, \mathrm{NaCl}$, butil alkohol, dan aquades.

\section{Peralatan Penelitian}

Peralatan laboratorium yang terdiri dari centrifuge (EBA 200 merek HETTICH), vacuum mini freeze drier (TOPT-10A), chiller (Samsung RR18), dan alat ekstraksi kolagen (beaker glass, gelas ukur, pengaduk, $\mathrm{pH}$ meter, dan lain-lain) digunakan dalam penelitian ini. Alat yang digunakan untuk pengujian antara lain timbangan analitik, oven (Memmert), FTIR Spectroscopy (Shimadzu PC-8201), dan SDSPAGE elektroforesis gel (DYCZ-24DN).

\section{Metode Penelitian \\ Penyiapan kulit kerbau}

Metode yang digunakan mengacu pada penelitian Mulyani et al. (2017a), yaitu kulit kerbau dicuci menggunakan air mengalir untuk menghilangkan larutan garam yang merupakan pengawet pada kulit. Kemudian kulit direndam dalam air kapur $2 \%(\mathrm{~b} / \mathrm{v})$ untuk menghilangkan rambut pada kulit. Selanjutnya, rambut dan lemak pada kulit dihilangkan dengan cara manual menggunakan pisau, lalu kulit dicuci kembali dengan air mengalir untuk mendapatkan $\mathrm{pH}$ kulit sekitar 7-7,5 kemudian kulit dipotong dadu dengan ukuran sekitar $1 \times 1 \mathrm{~cm}$, dan kulit kerbau siap untuk diekstraksi. 


\section{Ekstraksi kolagen dari kulit kerbau}

Metode ekstraksi kolagen mengacu pada percobaan yang dilakukan oleh Noorzai et al. (2020) yang telah dimodifikasi, yaitu potongan kulit kerbau ditimbang sebanyak 50 gram untuk masing-masing unit percobaan. Potongan kulit tersebut dimasukkan ke dalam erlenmeyer $500 \mathrm{ml}$, lalu direndam dalam larutan $\mathrm{NaOH} 0,1$ M dengan perbandingan 1:4 (b/v), kemudian erlenmeyer ditutup dengan kertas alumunium foil dan didiamkan selama 6 jam pada suhu kamar untuk menghilangkan komponen non-kolagen pada kulit. Setelah itu, sampel dikeluarkan dan dicuci dengan air mengalir hingga mencapai $\mathrm{pH}$ pada kondisi netral. Penghilangan lemak dilakukan dengan cara kulit kerbau direndam dengan larutan butil alkohol 8\% selama 18 jam, kemudian sampel dibilas kembali menggunakan aquades hingga bersih ( $\mathrm{pH}$ netral). Selanjutnya sampel diekstraksi dengan larutan asam asetat pada konsentrasi yang telah ditentukan $(0,5 \mathrm{M} ; 1 \mathrm{M}$; dan $1,5 \mathrm{M})$ dan dengan lama waktu ekstraksi yang juga telah ditentukan (48 jam dan 72 jam) pada suhu kamar. Hasil ekstraksi kemudian disaring untuk memisahkan residu dengan ekstrak (supernatan).

Supernatan dipresipitasi dengan cara menambahkan $\mathrm{NaCl1}$,8 Mhingga konsentrasi akhir larutan $0,9 \mathrm{M}$ (banyak $\mathrm{NaCl}$ yang ditambahkan disesuaikan dengan banyak supernatan yang akan dipresipitasi sesuai perhitungan), kemudian diaduk hingga diperoleh presipitat kolagen (proses salting-out). Presipitat didiamkan selama 24 jam dalam kondisi suhu kamar, kemudian disaring. Presipitat, yang berbentuk gumpalan kolagen, dimasukkan ke dalam plastik klip, sedangkan presipitat, yang mengendap selama penyaringan, didiamkan dalam tube sentrifuge selama 24 jam. Hasil pengendapan presipitat selanjutnya didialisis dengan cara presipitat dan sedikit aquades dimasukkan ke dalam membran selofan yang telah direndam menggunakan aquades selama 24 jam. Kemudian membran berisi kolagen direndam dalam larutan asam asetat $0,1 \mathrm{M}$ selama 24 jam (diulang sebanyak 3 kali dengan larutan asam asetat yang baru). Setelah dua kali penggantian larutan asam asetat tersebut, membran yang berisi kolagen direndam dengan aquades yang diganti setiap 3 jam sampai $\mathrm{pH}$ aquades mencapai kondisi netral. Kolagen pasca dialisis, diliofilisasi (freeze drying) selama 12 jam dalam wadah-wadah yang mudah dikeringkan, secara terpisah, sehingga diperoleh kolagen yang berbentuk seperti kapas berwarna putih, kemudian kolagen diberi silica gel.

\section{Pengujian}

Identifikasi karakteristik kolagen dari kulit kerbau meliputi nilai rendemen yang sesuai dengan penelitian Mulyani et al. (2017b) dan kadar air yang sesuai panduan AOAC (2005). Uji berat molekul menggunakan SDS-PAGE dengan metode Laemmli (1970) dan uji gugus fungsional dengan menggunakan FTIR yang mengacu pada penelitian Mulyani et al. (2017a).

\section{HASIL DAN PEMBAHASAN}

\section{Rendemen}

Rendemen (yield) merupakan salah satu cara untuk mengetahui apakah metode ekstraksi yang digunakan telah efektif serta efisien dalam menghasilkan kolagen atau belum. Semakin tinggi nilai rendemen maka menunjukkan semakin efektif metode yang digunakan dan perlakuan yang diaplikasikan semakin efisien (Febriansyah et al., 2019). Astiana et al. (2016) menambahkan bahwa rendemen juga menjadi parameter penting dalam menentukan tingkat ekonomis suatu produk. Rendemen kolagen kulit kerbau yang diekstraksi dengan konsentrasi asam asetat dan lama ekstraksi, yang berbeda, ditampilkan dalam Tabel 1.

Hasil analisis ragam menunjukkan bahwa tidak ada pengaruh interaksi antara konsentrasi asam asetat dengan lama ekstraksi terhadap rendemen, namun pada setiap peningkatan faktor konsentrasi asam asetat dan lama ekstraksi terdapat pengaruh yang nyata $(\mathrm{P}<0,05)$ terhadap peningkatan nilai rendemen. Hal tersebut disebabkan oleh peran ion $\mathrm{H}^{+}$dari asam asetat serta lamanya kontak antara pelarut asam dengan kulit kerbau. Mulyani et al. (2017b) menyatakan bahwa semakin meningkatnya konsentrasi asam, maka konsentrasi ion $\mathrm{H}^{+}$turut meningkat, sehingga menyebabkan semakin banyak ikatan silang pada daerah telopeptida sisi heliks yang terpecah, kemudian kolagen menjadi mudah terlarut. Semakin lama waktu ekstraksi akan menjadikan proses ekstraksi lebih sempurna, dimana kolagen yang terlarut semakin banyak dan hasil rendemen mengalami peningkatan (Hudha et al., 2012).

Hasil rendemen kulit kerbau, yang diperoleh, lebih rendah dibandingkan dengan penelitian yang telah dilakukan oleh Ferraro et al. (2017), yakni kolagen tulang sapi sebesar 89,2-95,8\%, 
Tabel 1. Rendemen kolagen kulit kerbau yang diekstraksi dengan asam asetat.

\begin{tabular}{|c|c|c|c|c|}
\hline \multirow{3}{*}{$\begin{array}{l}\text { Lama ekstraksi } \\
\text { (jam) }\end{array}$} & \multicolumn{3}{|c|}{ Konsentrasi asam asetat (M) } & \multirow{3}{*}{ Rata-rata $\pm \mathrm{SD}$} \\
\hline & 0,5 & 1 & 1,5 & \\
\hline & & $\%$ & & \\
\hline 48 & $0,75 \pm 0,11$ & $1,25 \pm 0,18$ & $1,37 \pm 0,20$ & $1,12 \pm 0,32^{\mathrm{x}}$ \\
\hline 72 & $1,45 \pm 0,18$ & $1,59 \pm 0,24$ & $2,07 \pm 0,27$ & $1,70 \pm 0,35^{\mathrm{y}}$ \\
\hline Rata-rata $\pm \mathrm{SD}$ & $1,10 \pm 0,40^{\mathrm{a}}$ & $1,42 \pm 0,27^{\mathrm{ab}}$ & $1,72 \pm 0,44^{\mathrm{b}}$ & \\
\hline
\end{tabular}

dan penelitian kolagen kulit sapi oleh Said et al. (2018), yakni sebesar 28\%. Nilai rendemen yang rendah diduga bahwa penggunaan jumlah asam asetat yang merupakan asam lemah masih kurang efektif untuk mengekstraksi kolagen dari kulit kerbau yang memiliki sifat tebal dan kuat. Asam asetat digolongkan sebagai asam lemah, yang memiliki konsentrasi ion $\mathrm{H}^{+}$yang rendah, sehingga dengan perlakuan asam asetat yang sedikit maka kelarutan kolagen dalam asam akan kurang maksimal (Paudi et al., 2020).

\section{Kadar Air}

Salah satu parameter yang menjadi syarat mutu kolagen adalah kadar air. Kadar air berpengaruh terhadap daya simpan karena berkaitan dengan aktivitas mikroba, enzim, dan kimiawi, seperti ketengikan, hingga aktivitas non enzimatis yang menyebabkan perubahan sifat organoleptik serta nilai mutu. Kadar air yang semakin tinggi akan menyebabkan semakin pendek masa simpan kolagen (Nurhidayah et al., 2019). Kadar air kolagen kulit kerbau yang diekstraksi dengan variasi konsentrasi asam asetat dan durasi ekstraksi disajikan dalam Tabel 2, dimana menunjukkan bahwa kadar air kolagen dari kulit kerbau memenuhi standar mutu kolagen menurut SNI 8076:2014 (BSN, 2014), yaitu maksimal sebesar $12 \%$.

Hasil analisis ragam menunjukkan bahwa konsentrasi asam asetat, lama ekstraksi, dan interaksi antara konsentrasi asam asetat dan lama ekstraksi memiliki pengaruh nyata $(\mathrm{P}<0,05)$ terhadap nilai kadar air. Berdasarkan Tabel 2, kadar air kolagen dari kulit kerbau cenderung berkurang seiring meningkatnya konsentrasi asam asetat. Hal ini diduga karena semakin tinggi konsentrasi asam asetat akan meningkatkan jumlah ion $\mathrm{H}^{+}$yang menyebabkan struktur kolagen menjadi semakin terbuka dan mengganggu ikatan antar protein yang kemudian menyebabkan daya ikat kolagen terhadap air melemah, sehingga air akan mudah terlepas atau menyublim saat proses pengeringan (freeze drying). Ulfah (2011) menyatakan bahwa penurunan kadar air kolagen kering dapat disebabkan oleh semakin terbukanya struktur kolagen dimana struktur yang lemah akan menyebabkan daya ikat air menjadi menurun. Seiring meningkatnya lama ekstraksi, kadar air kolagen kering semakin meningkat. Hal ini diduga karena air banyak terserap oleh kolagen selama proses perendaman.

Penetrasi air ke dalam jaringan kolagen melalui suatu ikatan hidrogen atau gaya elektrostatik antara gugus polar menyebabkan ditemukannya kandungan air pada kolagen (Romadhon et al., 2019). Azara (2017) berpendapat bahwa kadar air dipengaruhi oleh kehilangan air yang terjadi selama proses pengeringan dan penyerapan air pada saat perendaman. Ditinjau dari kadar air, kolagen dari kulit kerbau dengan konsentrasi asam asetat $1,5 \mathrm{M}$ yang diekstraksi selama 48 jam, merupakan perlakuan yang optimal karena memiliki kadar air yang paling rendah. Semakin rendah kadar air kolagen akan meningkatkan kualitas kolagen, karena memiliki umur simpan yang lebih panjang.

\section{Berat Molekul}

Berat molekul kolagen dari kulit kerbau diukur menggunakan SDS-PAGE. Hasil yang diperoleh berupa pita-pita protein, yang dibedakan berdasarkan berat molekulnya, yang setara dengan panjang rantai protein. Protein yang memiliki ukuran kecil akan lebih cepat melintasi gel, sehingga akan memiliki jarak tempuh yang lebih panjang dibandingkan protein dengan ukuran yang lebih besar (Astiana et al., 2016). Semakin berat molekul maka posisi pita protein akan semakin di atas. Erizal et al. (2014) menyatakan bahwa setiap molekul kolagen memiliki berat sekitar 300.000 dalton. Hasil SDS-PAGE kolagen dari kulit kerbau yang diekstraksi dengan asam asetat konsentrasi $1 \mathrm{M}$ dan lama ekstraksi 72 jam 
Tabel 2. Kadar air kolagen kulit kerbau yang diekstraksi dengan asam asetat.

\begin{tabular}{cccc}
\hline \multirow{2}{*}{ Lama ekstraksi (jam) } & \multicolumn{3}{c}{ Konsentrasi asam asetat (M) } \\
\cline { 2 - 4 } & 0,5 & $\%$ & 1,5 \\
\cline { 2 - 4 } & $4,49 \pm 0,38^{\mathrm{d}}$ & $3,40 \pm 0,20^{\mathrm{b}}$ & $2,57 \pm 0,13^{\mathrm{a}}$ \\
78 & $6,24 \pm 0,13^{\mathrm{e}}$ & $4,19 \pm 0,14^{\mathrm{cd}}$ & $3,89 \pm 0,26^{\mathrm{c}}$ \\
\hline
\end{tabular}

Keterangan: Nilai dengan superskrip yang berbeda menunjukkan perbedaan nyata $(\mathrm{P}<0,05)$.

yang merupakan perlakuan optimal berdasarkan rendemen disajikan pada Gambar 1.

Hasil dari SDS-PAGE menunjukkan bahwa pada semua perlakuan terdapat pita rantai $\alpha 1$, $\alpha 2$, dan $\beta$ yang masing-masing memiliki berat molekul sekitar $140 \mathrm{kDa}, 127 \mathrm{kDa}$, dan $224 \mathrm{kDa}$. Idrus et al. (2018) menyatakan bahwa struktur rantai $\alpha$ dan $\beta$ ditemukan pada berat molekul protein sekitar 135-245 kDa. Adanya rantai $\alpha 1$ dan $\alpha 2$ yang merupakan ciri khas dari kolagen dapat menunjukkan bahwa kolagen dari kulit kerbau, yang dihasilkan, dikategorikan kolagen tipe 1 (Djailani et al., 2016). Kolagen tipe 1 adalah salah satu jenis kolagen yang banyak terdapat pada jaringan kulit, tendon, dan tulang, serta umumnya terdiri dari rantai $\alpha 1$ dan $\alpha 2$ yang membentuk triple helix (Fawzya et al., 2016).

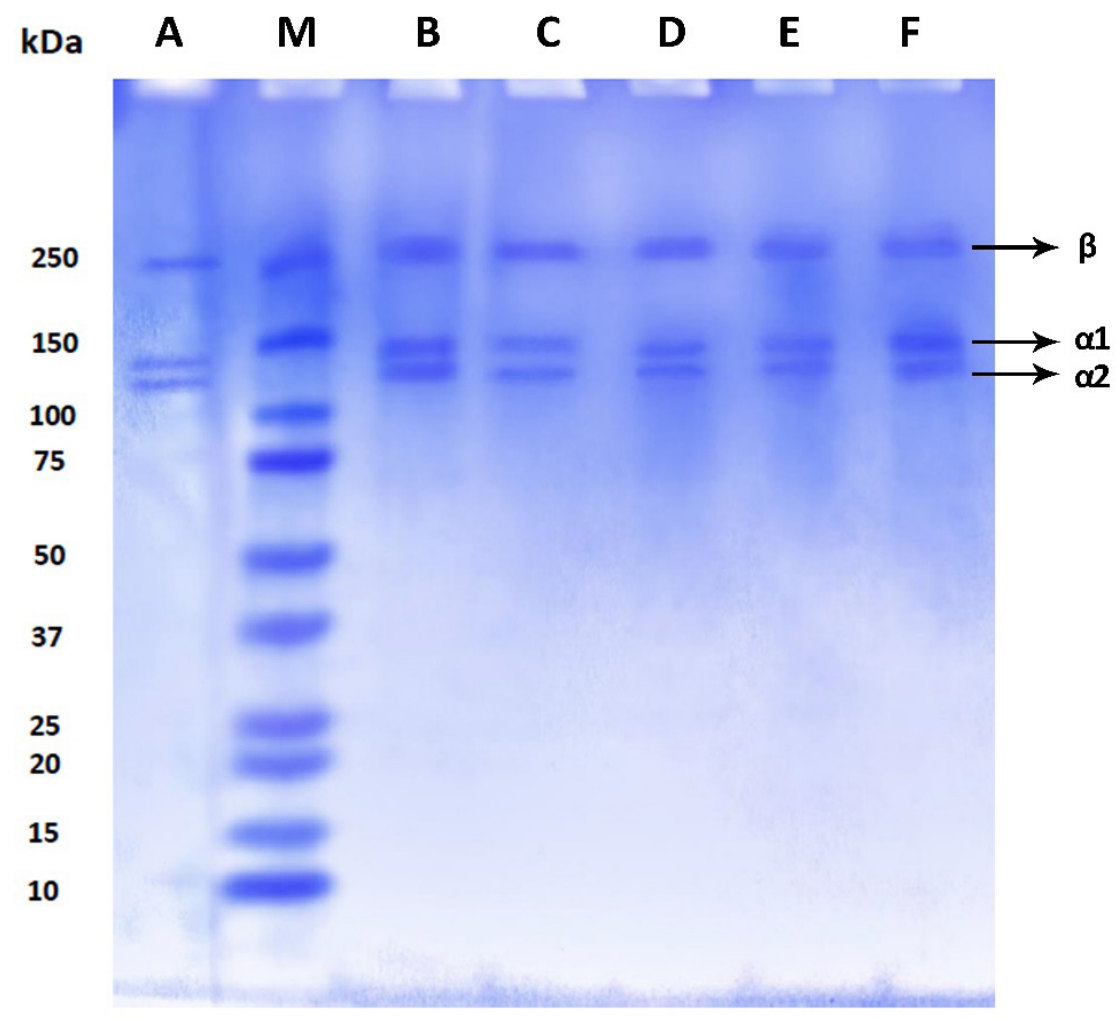

Gambar 1. Elektroforesis kolagen dari kulit kerbau dengan marker (M), kolagen dengan konsentrasi asam asetat 1,5 $\mathrm{M}$ dan lama ekstraksi 72 jam (A), kolagen dengan konsentrasi asam asetat 1M dan lama ekstraksi 72 jam (B), kolagen dengan konsentrasi asam asetat 0,5 M dan lama ekstraksi 72 jam (C), kolagen dengan konsentrasi asam asetat 1,5 M dan lama ekstraksi 48 jam (D), kolagen dengan konsentrasi asam asetat $1 \mathrm{M}$ dan lama ekstraksi 48 jam (E), dan kolagen dengan konsentrasi asam asetat 0,5 $\mathrm{M}$ dan lama ekstraksi 48 jam (F). 
Kolagen dari kulit kerbau terdiri dari komponen kimia yang memiliki berat molekul tinggi, yakni struktur $\beta$ (rantai dimer $\alpha$ ). Struktur rantai $\beta$ menjelaskan bahwa terdapat ikatan silang (cross linked) dalam molekul kolagen dimana semakin tebal pita protein struktur $\beta$ menandakan jumlah kolagen yang mengalami cross linking semakin banyak (Astiana et al., 2016). Keberadaan rantai $\beta$ menunjukkan bahwa kolagen kulit kerbau yang dihasilkan semua perlakuan konsentrasi asam asetat dan lama ekstraksi belum dapat menguraikan rantai triple helix pada kolagen menjadi rantai tunggal $\alpha$ heliks. Hal tersebut terjadi karena ikatan silang pada daerah telopeptida pada sisi heliks belum terpecah secara maksimal oleh pelarut asam (Pamungkas et al., 2018). Diketahui bahwa pada pola elektroforesis tidak terdapat pita protein yang berada di bawah pita rantai $\alpha$. Menurut Djailani et al. (2016), tidak adanya keberadaan pita protein di bawah rantai $\alpha$ menunjukkan bahwa tidak terdapat peptida lain yang terbentuk akibat terjadinya degradasi kolagen. Degradasi protein kolagen menjadi gelatin terjadi karena struktur rantai asam amino penyusun kolagen mengalami pemutusan ikatan kovalen berlebih sehingga rantai asam amino terpotong menjadi lebih pendek dan berat molekul kolagen menjadi rendah (Santoso et al., 2015).

\section{Gugus Fungsi}

Spektroskopi FTIR dapat digunakan untuk mengidentifikasi gugus fungsional dan struktur sekunder (Mulyani et al., 2017a). Pada pengujian gugus fungsional kolagen yang dilakukan pada salah satu perlakuan, yaitu ekstraksi dengan asam asetat pada konsentrasi 1,5 M selama 72 jam, diperoleh grafik sebagaimana disajikan pada Gambar 2.

Berdasarkan spektrum FTIR terdeteksi adanya daerah serapan khas kolagen yang disebut amida A, amida B, amida I, amida II, dan amida III yang masing-masing memiliki puncak serapan pada panjang gelombang $3425,58 \mathrm{~cm}^{-1}, 2931,80$ $\mathrm{cm}^{-1}, 1651,07 \mathrm{~cm}^{-1}, 1543,05 \mathrm{~cm}^{-1}$, dan 1242,16 $\mathrm{cm}^{-1}$. Gugus amida A umumnya ditemukan pada wilayah serapan $3350-3550 \mathrm{~cm}^{-1}$ yang ditandai adanya gugus NH (gugus amina). Posisi puncak serapan amida A dipengaruhi oleh keterlibatan dari gugus $\mathrm{OH}$ (hidroksil) yang menunjukkan adanya partisipasi aktif dari molekul air pada proses ekstraksi kolagen (Safithri et al., 2019). Gugus amida B memiliki wilayah serapan 2915$2935 \mathrm{~cm}^{-1}$ yang menunjukkan adanya gugus $\mathrm{CH}_{2}$. Gugus amida I pada kolagen dari kulit kerbau memiliki wilayah serapan 1600-1700 $\mathrm{cm}^{-1}$. Puncak gugus amida I menunjukkan adanya gugus karbonil, yakni ikatan $\mathrm{C}=\mathrm{O}$ di sepanjang rantai polipeptida (Devi et al., 2017), serta menjadi penanda dari struktur sekunder protein. Gugus amida II menunjukkan adanya ikatan $\mathrm{NH}$ dan CN pada kisaran wilayah serapan $1480-1575 \mathrm{~cm}^{-}$ ${ }^{1}$. Gugus fungsi yang terakhir yakni gugus amida III memiliki wilayah serapan $1229-1301 \mathrm{~cm}^{-1}$, yang menujukkan adanya ikatan $\mathrm{NH}$ dan $\mathrm{CH}$ pada

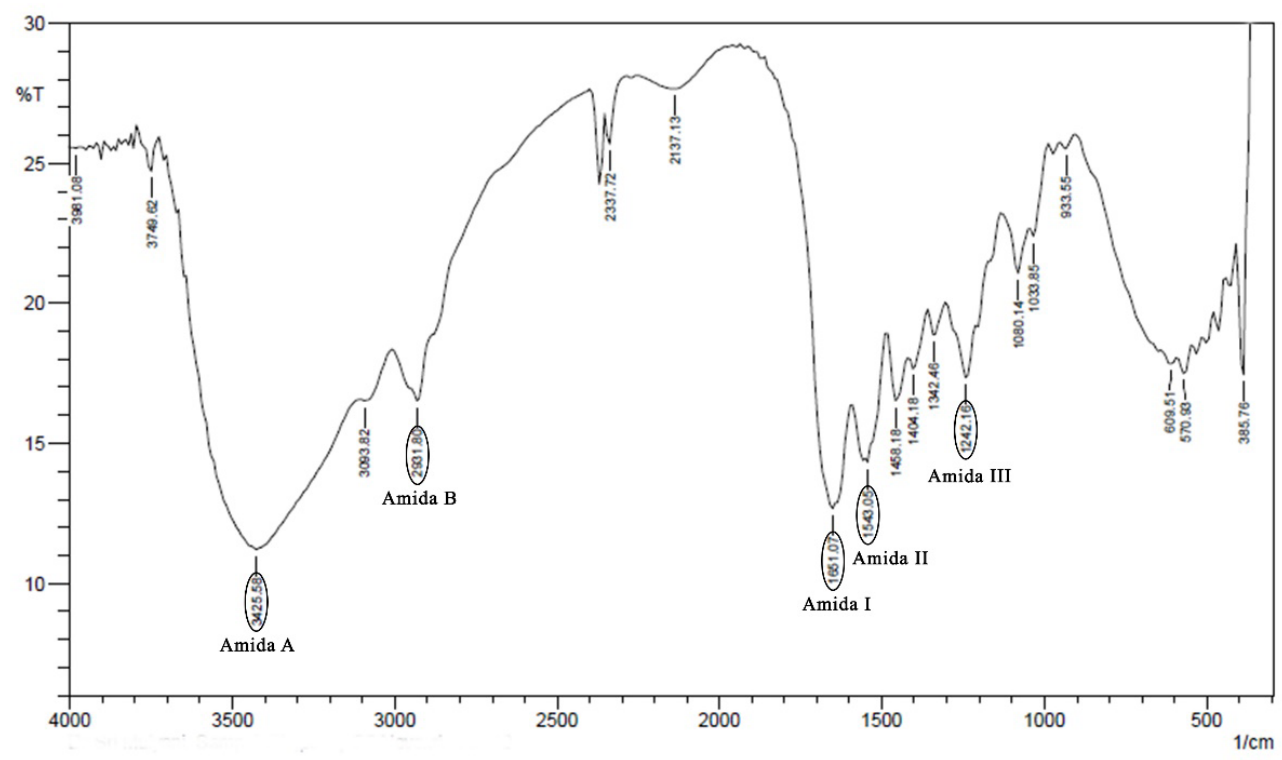

Gambar 2. Spektrum FTIR kolagen dari kulit kerbau setelah ekstraksi dengan asam asetat $1 \mathrm{M}$ selama 72 jam. 
ikatan peptida (Safithri et al., 2020).

Disamping itu, terdapat hubungan antara intensitas gugus amida III dengan struktur triple helix (Simamora et al., 2019). Hasil analisis gugus fungsi pada kolagen menggunakan FTIR dapat memperlihatkan adanya struktur triple helix yang ditunjukkan dengan nilai rasio serapan antara amida III dan puncak serapan pada $1450 \mathrm{~cm}^{-1}$ apabila mendekati 1,0 (Silva et al., 2014). Nilai rasio serapan antara amida III $\left(1242,16 \mathrm{~cm}^{-1}\right)$ dan $1458,18 \mathrm{~cm}^{-1}$ pada kolagen dari kulit kerbau yakni 0,99 . Hal tersebut mengindikasikan bahwa kolagen dari kulit kerbau belum terdegradasi menjadi gelatin. Kolagen yang terdenaturasi dan kehilangan struktur triple helix menjadi gelatin memiliki intensitas rasio 0,59 (Safithri et al., 2020). Berdasarkan hasil spektrum FTIR kolagen dari kulit kerbau menunjukkan adanya gugusgugus khas penyusun kolagen, adanya gugus triple helix, dan rasio perbandingan antara amida III dan $1450 \mathrm{~cm}^{-1}$ yang mendekati satu, sehingga dapat disimpulkan bahwa kolagen kulit kerbau dengan perlakuan terbaik merupakan kolagen dan belum mengalami degradasi menjadi gelatin.

\section{KESIMPULAN}

Ekstraksi kolagen dari kulit kerbau optimum dilakukan dengan konsentrasi asam asetat 1 M dengan lama ekstraksi 72 jam yang dapat menghasilkan kolagen dengan rendemen $1,42 \pm 0,27 \%$, berdasarkan faktor konsentrasi, dan $1,70 \pm 0,35 \%$ berdasarkan faktor lama ekstraksi. Kadar air kolagen $4,19 \pm 0,14 \%$, teridentifikasi sebagai kolagen tipe I, dan belum mengalami degradasi menjadi gelatin.

\section{UCAPAN TERIMA KASIH}

Penelitian ini didanai oleh Kementerian Riset, Teknologi, dan Pendidikan Tinggi Republik Indonesia di bawah koordinasi Lembaga Penelitian dan Pengabdian kepada Masyarakat (LPPM) Universitas Diponegoro melalui skema Penelitian Dasar Unggulan Perguruan Tinggi (PDUPT) 2021.

\section{DAFTAR PUSTAKA}

AOAC (Association of Analytical Chemist). (2005). Official methods of analyses association (18th ed.). Washington DC, USA: Association of Analytical Chemist.

Ariyanti, A., Dewi, M., Hapsari, A. P., \& Mashadi, S. (2018). Perbandingan kadar kolagen cangkang kerang darah (Anadara granosa) dengan cangkang kerang hijau (Mytilus viridis) di Bandengan, Kendal, Jawa Tengah. Jurnal Pharmascience, 5(2), 134-142. https://doi.org/10.20527/jps. v5i2.5795

Astiana, I., Nurjanah, \& Nurhayati, T. (2016). Karakteristik kolagen larut asam dari kulit ikan ekor kuning. Jurnal Pengolahan Hasil Perikanan Indonesia, 19(1), 79-93. https://doi.org/10.17844/ iphpi.2016.19.1.79

Ata, S. T., Yulianty, R., Sami, F. J., \& Ramli, N. (2016). Isolasi kolagen dari kulit dan tulang ikan cakalang (Katsuwonus pelamis). Journal of Pharmaceutical and Medicinal Sciences, 1(1), 27-30.

Azara, R. (2017). Pembuatan dan analisis sifat fisikokimia gelatin dari limbah kulit ikan kerapu (Ephinephelus sp.). Jurnal Teknologi Pangan, 11(1), 62-69.

BSN (Badan Standardisasi Nasional). (2014). Standard Nasional Indonesia SNI 01-8076-2014: Kolagen kasar dari sisik ikan - Syarat mutu dan pengolahan. Jakarta, Indonesia: BSN.

Darmanto, Y. S., Agustini, T. W., \& Swastawati, F. (2012). Efek kolagen dari berbagai jenis tulang ikan terhadap kualitas miofibril protein ikan selama proses dehidrasi. Jurnal Teknologi dan Industri Pangan, 23(1), 36-36.

Devi, H. L. N. A., Suptijah, P., \& Nurilmala, M. (2017). Efektifitas alkali dan asam terhadap mutu kolagen dari kulit ikan patin. Jurnal Pengolahan Hasil Perikanan Indonesia, 20(2), 255-256. https://doi. org/10.17844/jphpi.v20i2.17906

Djailani, F., Trilaksani, W., \& Nurhayati, T. (2016). Optimasi ekstraksi dan karakterisasi kolagen dari gelembung renang ikan cunang dengan metode asam-hidro-ekstraksi. Jurnal Pengolahan Hasil Perikanan Indonesia, 19(2), 156-167. https://doi. org/10.17844/jphpi.v19i2.13461

Erizal, E., Abbas, B., Setyo A. K. R., Sulistioso, G. S., \& Sudirman. (2014). Pengaruh iradiasi gamma pada sifat fisiko-kimia kolagen dalam larutan. Jurnal Sains Materi Indonesia, 15(4), 221-225. https:// doi.org/10.17146/jsmi.2014.15.4.4342

Fawzya, Y. N., Chasanah, E., Poernomo, A., \& Khirzin, M. H. (2016). Isolasi dan karakterisasi parsial kolagen dari teripang gamma (Stichopus variegatus). Jurnal Pascapanen dan Bioteknologi Kelautan dan Perikanan, 11(1), 91-100. https:// doi.org/10.15578/jpbkp.v11i1.284

Febriansyah, R., Pratama, A., \& Gumilar, J. (2019). Pengaruh konsentrasi $\mathrm{NaOH}$ terhadap rendemen, kadar air dan kadar abu gelatin ceker itik (Anas platyrhynchos Javanica). Jurnal Ilmu dan Teknologi Hasil Ternak, 14(1), 1-10. https://doi. org/10.21776/ub.jitek.2019.014.01.1

Ferraro, V., Gaillard-Martinie, B., Sayd, T., Chambon, C., Anton, M., \& Santé-Lhoutellier, V. (2017). Collagen type I from bovine bone. Effect of animal 
age, bone anatomy and drying methodology on extraction yield, self-assembly, thermal behaviour and electrokinetic potential. International Journal of Biological Macromolecules, 97, 55-66. https:// doi.org/10.1016/j.ijbiomac.2016.12.068

Hudha, M. I., Sepdwiyanti, R., \& Sari, S. D. (2012). Ekstraksi karaginan dari rumput laut (Eucheuma spinosum) dengan variasi suhu pelarut dan waktu operasi. Jurnal Teknik Kimia, 6(2), 50-53.

Idrus, S., Hadinoto, S., \& Kolanus, J. (2018). Karakterisasi kolagen gelembung renang tuna sirip kuning (Thunnus albacares) dari perairan maluku menggunakan ekstraksi asam. Biopropal Industri, 9(2), 87-94. https://doi.org/10.36974/ jbi.v9i2.4020

Kolanus, J. P., Hadinoto, S., \& Idrus, S. (2019). Karakteristik kolagen larut asam dari kulit ikan tuna (Thunnus albacores) dengan metode hidroekstraksi. Jurnal Riset Teknologi Industri, 13(1), 99-110. $\quad$ https://doi.org/10.26578/jrti. $\underline{\mathrm{v} 13 \mathrm{i} 1.4994}$

Laemmli, U. K. (1970). Cleavage of structural proteins during the assembly of the head of bacteriophage T4. Nature, 227, 680-685. https:// doi.org/10.1038/227680a0

Mulyani, S., Setyabudi, F. M. C. S., Pranoto, Y., \& Santoso, U. (2017a). The effect of pretreatment using hydrochloric acid on the characteristics of buffalo hide gelatin. Journal of the Indonesian Tropical Animal Agricultureculture, 42(1), 14-22. https://doi.org/10.14710/jitaa.42.1.14-22

Mulyani, S., Setyabudi, F. M. C. S., Pranoto, Y., \& Santoso, U. (2017b). Physicochemical properties of gelatin extracted from buffalo hide pretreated with different acids. Korean Journal for Food Science of Animal Resources, 37(5), 708-715. https://doi.org/10.5851/kosfa.2017.37.5.708

Noorzai, S., Verbeek, C. J. R., Lay, M. C., \& Swan, J. (2020). Collagen extraction from various waste bovine hide sources. Waste and Biomass Valorization, 11, 5687-5698. https://doi. org/10.1007/s12649-019-00843-2

Nurhidayah, B., Soekendars, E., \& Erviani, A. E. (2019). Kandungan kolagen sisik ikan bandeng Chanos-chanos dan sisik ikan nila Oreochromis niloticus. BIOMA: Jurnal Biologi Makassar, 4(1), 39-47. https://doi.org/10.20956/bioma.v4i1.6341

Pamungkas, B. F., Supriyadi, S., Murdiati, A., \& Indrati, R. (2018). Ekstraksi dan karakterisasi kolagen larut asam dan pepsin dari sisik haruan (Channa striatus) kering. Jurnal Pengolahan Hasil Perikanan Indonesia, 21(3), 513-521. https://doi.org/10.17844/jphpi.v21i3.24734
Paudi, R., Sulistijowati, R., \& Mile, L. (2020). Rendemen kolagen kulit ikan bandeng (Chanos chanos) segar hasil ekstraksi asam asetat. Jambura Fish Processing Journal, 2(1), 21-27. https://doi. org/10.37905/jfpj.v2i1.5930

Rizk, M. A., \& Mostafa, N. Y. (2016). Extraction and characterization of collagen from buffalo skin for biomedical applications. Oriental Journal of Chemistry, 32(3), 1601-1609.

Romadhon, R., Darmanto, Y. S., \& Kurniasih, R. A. (2019). Karakteristik kolagen dari tulang, kulit, dan sisik ikan nila. Jurnal Pengolahan Hasil Perikanan Indonesia, 22(2), 403-410. https://doi. org/10.17844/jphpi.v22i2.28832

Safithri, M., Tarman, K., Suptijah, P., \& Widowati, N. (2019). Karakteristik fisikokimia kolagen larut asam dari kulit ikan parang-parang (Chirocentrus dorab). Jurnal Pengolahan Hasil Perikanan Indonesia, 22(3), 441-452. https://doi. org/10.17844/jphpi.v22i3.28924

Safithri, M., Tarman, K., Suptijah, P., \& Sagita, S. N. (2020). Karakteristik kolagen larut asam teripang gama (Stichopus variegatus). Jurnal Pengolahan Hasil Perikanan Indonesia, 23(1), 166-177. https://doi.org/10.17844/jphpi.v23i1.31063

Said, M. I., Burhan, B., Tensi, T., \& Haerati, H. (2018). Synthesis of collagen from Bali cattle's hide using a combination of acid and alkali on the extracting process. Journal of the Indonesian Tropical Animal Agriculture, 43(3), 247-256. https://doi. org/10.14710/jitaa.43.3.247-256

Santoso, C., Surti, T., \& Sumardianto. (2015). Perbedaan penggunaan konsentrasi larutan asam sitrat dalam pembuatan gelatin tulang rawan ikan pari mondol (Himantura gerrardi). Jurnal Pengolahan dan Bioteknologi Hasil Perikanan, 4(2), 106-114.

Silva, T. H., Moreira-Silva, J., Marques, A. L. P., Domingues, A., Bayon, Y., \& Reis, R. L. (2014). Marine origin collagens and its potential applications. Marine Drugs, 12(12), 5881-5901. https://doi.org/10.3390/md12125881

Simamora, G. R. R., Trilaksani, W., \& Uju, U. (2019). Profiling kolagen gelembung renang ikan patin (Pangasius sp.) melalui proses enzimatis. Jurnal Pengolahan Hasil Perikanan Indonesia, 22(2), 299-310. https://doi.org/10.17844/jphpi. v22i2.27717

Ulfah, M. (2011). Pengaruh konsentrasi larutan asam asetat dan lama waktu perendaman terhadap sifatsifat gelatin ceker ayam. Agritech, 31(3), 161167. https://doi.org/10.22146/agritech. 9740 